\title{
PENGARUH PENERAPAN SISTEM INFORMASI PERPUSTAKAAN (SIPUS TERPADU VERSI 3) TERHADAP KINERJA PELAYANAN SIRKULASI DI PERPUSTAKAAN UNIVERSITAS GADJAH MADA
}

\author{
Oleh: Haryanta
}

Intisari

Penelitian ini bertujuan untuk mengetahui bagaimana pengaruh penerapan Sistem Informasi Perpustakaan terhadap kinerja Pelayanan Sirkulasi di Perpustakaan Universitas Gadjah Mada. Model penelitian ini, menggunakan variabel penggunaan Sistem Informasi Perpustakaan (SIPUS Terpadu Versi 3) sebagai variabel independen, dan variabel kinerja pelayanan sirkulasi sebagai variabel dependen. Dimana variabel Penggunaan Sistem Informasi Perpustakaan (SIPUS Terpadu Versi 3) diurai menjadi subvariabel-subvariabel berdasarkan karakteristik sistem informasi menurut Delone dan McLean (2003). Metode pengumpulan data yang digunakan adalah melalui kuesioner yang disebarkan pada staf perpustakaan yang bertugas di bagian layanan sirkulasi dan bagian lainnya yang bertugas perpanjangan waktu (lembur) di pelayanan sirkulasi. Dari 40 kuesioner yang didistribusikan, semuanya kembali dan layak untuk dianalisis lebih lanjut. Analisis data dilakukan dengan analisis regresi menggunakan Program SPSS versi 12 for Windows.

Hasil penelitian menunjukan bahwa terdapat hubungan yang signifikan dan positif yang ditunjukan dengan angka signifikansi sebesar 0,000 lebih kecil dari 0,05 (signifikan) dan koefisien regresi sebesar 0,175 (positif) antara Penggunaan Sistem Informasi Perpustakaan (SIPUS Terpadu Versi 3) dan Kinerja Pelayanan Sirkulasi. Berdasarkan pedoman Uji Signifikansi korelasi Product Moment, diperoleh koefisien determinasi adjusted R2 sebesar 0,413 yang termasuk dalam kategori sedang. Dari pengujian model diperoleh bahwa variabel penggunaan Sistem Informasi Perpustakaan (SIPUS Terpadu versi 3) mempengaruhi kinerja pelayanan sirkulasi sebesar $41,3 \%$ sedangkan sisanya 58,7\% (100\% - 41,3\%) dipengaruhi oleh variabel yang lain diluar model.

Kata kunci: Sistem Informasi Perpustakaan, Karakteristik Sistem Informasi, Kinerja, Pelayanan Sirkulasi

*) Pustakawan UGM

\section{Pendahuluan}

Perkembangan teknologi informasi dan komunikasi memberikan pengaruh dalam pengelolaan perpustakaan. Perpustakaan sebagai pengelola informasi dan pengetahuan banyak memanfaatkan komputer untuk berbagai keperluan. Beberapa pertimbangan perpustakaan memanfaatkan komputer antara lain, meningkatnya; (1) tuntutan kualitas pelayanan perpustakaan, (2) tuntutan untuk menggunakan koleksi secara bersama, (3) kebutuhan untuk lebih mengefektifkan tenaga, (4) kebutuhan akan efisiensi waktu, (5) ragam informasi yang dikelola, dan (6) kebutuhan akan kecepatan pelayanan (Dikti, 2004:20). Pendapat senada, tentang alasan perpustakaan memanfaatkan teknologi informasi dan komunikasi dinyatakan oleh Saleh $(2006: 1)$ : (1) tuntutan terhadap kuantitas dan pelayanan perpustakaan, (2) tuntutan terhadap penggunaan koleksi secara bersama, (3) kebutuhan untuk mengefektifkan sumberdaya manusia, (4)tuntutan terhadap efisien waktu, dan (5) keragaman informasi yang dikelola.

Dalam upaya meningkatkan kinerja pelayanan, banyak ahli berpendapat bahwa sistem informasi merupakan alternatif atau solusi yang tepat. Hal ini sesuai dengan pernyataan Rockart dan Short yang dikutip Malhotra (1992) dalam Tjokronolo (2007:18) bahwa sistem informasi akan memungkinkan organisasi dapat menghadapi tekanan, kekuatan persaingan, dan peningkatan kinerja perpustakaan dengan dilengkapi sistem pengelolaan yang efektif dan saling ketergantungan antar fungsi/struktur dalam organisasi.

Disamping itu perkembangan teknologi informasi (TI) telah memberikan berbagai sarana dan kemudahan bagi manajemen dalam mengelola bisnis dan pembuatan keputusannya. Sistem informasi yang didukung TI dapat memberikan nilai tambah bagi organisasi jika didesain menjadi informasi yang efektif. Namun demikian, pengukuran penilaian kualitas suatu sistem informasi yang efektif sulit dilakukan secara langsung seperti pengukuran biaya-manfaat (Laudon dan Laudon (2000) dalam Radityo dan Zulaikha (2007:2). Banyak penelitian telah dilakukan untuk mengidentifikasikan faktor-faktor 
yang menyebabkan kesuksesan sistem informasi. Salah satu penelitian yang terkenal adalah yang dilakukan oleh DeLone and McLean (2003). Menurut Jogiyanto (2007: 3) bahwa DeLone dan McLean (2003) melakukan studi yang mendalam mengenai kesuksesan sistem informasi. Mereka menemukan bahwa kesuksesan sebuah sistem informasi dapat direpresentasikan oleh karakteristik kualitatif dari sistem informasi itu sendiri (system quality), kualitas luaran dari sistem informasi (information quality), kualitas dari pelayanan sistem (service quality), konsumsi terhadap output (use), respon pengguna terhadap sistem informasi (user satisfication), pengaruh sistem informasi terhadap kinerja organisasi (organizational impact).

Perpustakaan Universitas Gadjah Mada melalui PT. Gamatechno telah mengembangkan dan menerapkan sebuah sistem informasi perpustakaan yaitu Sistem Informasi Perpustakaan (SIPUS) Terpadu versi 3 (tiga) untuk menjawab kebutuhan internal akan adanya sistem informasi perpustakaan yang baik dan sesuai kebutuhan. Penggunaan Sistem Informasi Perpustakaan (SIPUS Terpadu versi 3) bertujuan untuk meningkatkan kinerja pelayanan sirkulasi di Perpustakaan Universitas Gadjah Mada. Kegiatan pelayanan sirkulasi menurut Qalyubi (2003:221), meliputi; peminjaman, pengembalian, pernungutan denda, pendaftaran anggota, baca di tempat, penagihan, pembuatan statistik, dan hubungan masyarakat. Sistem Informasi Perpustakaan (SIPUS Terpadu versi 3) telah mampu mendukung kegiatan pelayanan sirkulasi karena beberapa kegiatan sirkulasi seperti peminjaman, pengembalian, pemungutan denda, histori anggota, histori buku, rekap laporan untuk statistik, penagihan keterlambatan pengembalian, dan penelusuran koleksi telah terakomodasi pada Sistem Informasi Perpustakaan (SIPUS Terpadu versi 3).

Hasil pengamatan sementara yang dilakukan terhadap penggunaan Sistem Informasi Perpustakaan (SIPUS Terpadu Versi 3) di Perpustakaan Universitas Gadjah Mada terdapat beberapa hal yang menarik. Pada saat transaksi peminjaman di pelayanan sirkulasi sering dijumpai ketidaksesuaian antara barcode pada database dengan barcode yang ada pada buku, yang mana barcode adalah sebagai wakil dari record eksemplar buku. Disamping itu pencari informasi menemukan suatu judul buku yang terjawab tersedia dalam OPAC atau tidak dalam status te rpinjam, tetapi tidak ditemukan di rak buku. Juga ada ketidak konsistenan tanggal kembali pada transaksi peminjaman dan perpanjangan pinjaman. Meski demikian penggunaan Sistem Informasi Perpustakaan (SIPUS Terpadu Versi 3) sangat membantu dan meningkatkan kinerja pelayanan sirkulasi di Perpustakaan Universitas Gadjah Mada.

Melihat pentingnya sistem informasi untuk perpustakaan dan untuk mengetahui bagaimana pengaruh penggunaan Sistem Informasi Perpustakaan (SIPUS Terpadu Versi 3) terhadap kinerja pelayanan sirkulasi di Perpustakaan Universitas Gadjah Mada, maka perlu diuji kesuksesan sistem informasi tersebut. Adapun judul penelitian yang penulis angkat adalah "Pengaruh Penggunaan Sistem Informasi Perpustakaan (SIPUS Terpadu Versi 3) Terhadap Kinerja Pelayanan Sirkulasi di Perpustakaan Universitas Gadjah Mada".

\section{Tinjuan Pustaka}

\section{A. Sistem Informasi Perpustakaan}

Sistem informasi perpustakaan termasuk dalam kajian sistem informasi manajemen (SIM). Oetomc (2006:173) memasukan sistem informas: perpustakaan dalam sistem informasi manajemer. berdasarkan bidang minat perusahaan/organisasi Berdasar definisi sistem informasi manajemer menurut Oetomo (2006:169) maka definisi sistem informasi perpustakaan adalah suatu sistem yan€ dirancang untuk menyediakan informasi gunc mendukung keputusan pada kegiatan manajemer perpustakaan seperti perencanaan, pemrakarsaan pengorganisasian, dan pengendalian dalam suat organisasi perpustakaan.

Lancaster (1988) dalam Hak (2005:8) membag kegiatan-kegiatan yang ada di perpustakaan it menjadi dua kelompok. Kegiatan pertami berhubungan dengan organisasi dan pengawasar sumber-sumber informasi. Kegiatan-kegiatan in berupa layanan teknis yang menghasilkan berbaga macam alat bantu (katalog, bibliografi, klasifikas rak, dan sejenisnya) yang akan membantu kegiatar kelompok keduanya, yaitu pelayanan publik Layanan publik kemudian dibagi lagi menjadi dui kelompok: demand service dan notification service Layanan yang pertama bersifat pasif menunggt respon atas permintaan para pemustaka, sedangkar yang kedua lebih dinamis dengan mencob: mendisain pelayanan untuk diinformasikan kepad: para pengguna sehingga menjadi tertarik.

Tiwari (2002) dalam Hak (2005:8) menjelaska1 bahwa yang menjadi fokus dalam otomas perpustakaan adalah sistem, sumber informasi, das pengguna yang terkoneksi, dimana perkembangas 
komputer akan diikuti dengan perkembangan penggunaan jaringan dan internet. Sistem informasi manajemen perpustakaan terintegrasi yang menerapkan modul-modul standar seperti sirkulasi, pengkatalogan, pengadaan, akses katalog online dan jaringan kerjasama melalaui fasilitas internet.

Cohn dkk. (2001) yang sejalan dengan Clayton dan Batt (1992) dalam Hak (2005:8) memberikan sebuah gambaran bahwa desain sistem yang sedang berkembang akhir-akhir ini lebih menekankan pada manfaat pendekatan otomasi terintegrasi. Otomasi terintegrasi memanfaatkan sebuah basis data dan program aplikasi yang mendukung pelaksanaan fungsi-fungsi teknis: pengadaan, sirkulasi, pengawasan serial dan katalog yang dapat diakses secara online, dan sistem terintegrasi dengan basis data tunggal ini akan mengurangi duplikasi data sehingga dapat meningkatkan efesien dan efektifitas. Hak (2005:9) dengan mengambil apa yang disampaikan Tiwari dan Cohn, mengatakan bahwa modul dasar sistem informasi perpustakaan setidaknya mencakup fungsi pengadaan, pengatalogan (pengolahan), sirkulasi, pengawasan serial, dan penelusuran katalog online. Sedangkan Rowley (1998) dalam Hak (2005:9) menyatakan bahwa fokus sistem informasi manajemen perpustakaan adalah untuk mendukung pelayanan secara efektif bagi pengguna, manajemen pengadaan, dan secara umum manajemen pelayanan-pelayanan yang diberikan oleh perpustakaan dan badan-badan lainnya yang menyelenggarakan akses terhadap koleksi-koleksi dokumen.

Berdasarkan pendapat-pendapat di atas, sistem informasi perpustakaan mengandung pengertian sebuah sistem informasi yang terotomasi dan terintegrasi, untuk menyajikan informasi guna mendukung fungsi operasional, manajemen, dan pengambilan keputusan dalam suatu perpustakaan.

\section{B. Karakteristik Sistem Informasi}

Dalam penelitian yang dilakukan DeLone dan McLean (2003) seperti yang dikemukakan Jogiyanto (2007) dalam bukunya yang berjudul "Model Kesuksesan Sistem Teknologi Informasi" bahwa karakteristik dari sistem informasi berguna untuk mengetahui kesuksesan suatu sistem yang terdiri dari (1) kualitas sistem (system quality), (2) kualitas informasi (information quality), (3) Minat pemakaian sistem (intention to use), (4) kepuasan pengguna (user satisfication), dan (5) kualitas jasa sistem informasi (service quality).

\section{a. Kualitas Sistem (System Quality)}

Pada karakteristik ini beberapa peneliti karakteristik dari sistem informasi yang menghasilkan informasi. Dalam mengevaluasi kontribusi sistem teknologi informasi kepada perpustakaan, beberapa peneliti telah melakukan studi pada sistem itu sendiri. Diantaranya Hamilton dan Chervany (1981) dalam Jogiyanto (2007:13) menggunakan pengukuran-pengukuran kualitas sistem sebagai berikut ini, yang digunakan untuk mengukur kualitas sistem informasi: (1) kekinian data diusulkan (proposes data currency), (2) waktu respon (response time), (3) keakuratan data (data accuracy), (4) keandalan (reliability); (5) kelengkapan (completeness), (6) keluwesan sistem (system flexibility), dan (7) kemudahan penggunaan (ease of use).

Ketujuh alat ukur kualitas sistem informasi tersebut di atas yaitu kekinian data, waktu respon, keakuratan data, keandalan, kelengkapan, keluwesan sistem, dan kemudahan penggunaan akan digunakan sebagai indikator untuk mengukur tingkat kesuksesan sistem informasi berdasarkan karakteristik kualitas sistem.

\section{b. Kualitas Informasi (Information Quality)}

Pada karakteristik ini beberapa peneliti mengukur kualitas informasi dari akurasi, output sistem, dampak kegunaan, waktu dan kualitas informasi dari sistem dan yang utama adalah informasi yang dihasilkan untuk menyajikan sebuah laporan. Menurut Amsyah (2001:316) kualitas informasi ditentukan oleh lima faktor, yaitu :

1) Ketelitian (accuracy)

Artinya informasi harus bebas dari kesalahankesalahan, tidak bias, dan tidak menyesatkan. Kesalahan-kesalahan itu dapat berupa kesalahan perhitungan maupun akibat gangguan (noise) yang dapat merusak informasi tersebut.

2) Ketepatan waktu (timeliness)

Informasi harus disajikan secara tepat waktu, mengingat informasi akan menjadi dasar dalam pengambilan keputusan. Keterlambatan informasi akan mengakibatkan kekeliruan dalam pengambilan keputusan.

3) Kelengkapan (complete)

Kadang-kadang manajer menghadapi suatu keputusan yang harus dibuat dengan informasi yang teliti, waktu yang tepat, tetapi informasinya tidak lengkap. Ketidaklengkapan informasi sering kali dapat tertundanya pengambilan keputusan. 
4) Ringkas (compendious)

Informasi yang bernilai adalah informasi yang ringkas dan langsung mengenai sasaran yang diperlukan (to the point).

5) Kesesuaian (relevancy)

Informasi hendaklah sesuai dengan keperluan pekerjaan atau keperluan manajemen dan sesuai dengan tujuan yang akan dicapai.

Kelima faktor tersebut di atas yaitu ketelitian, ketepatan waktu, kelengkapan, ringkas, dan kesesuaian dijadikan sebagai indikator untuk mengukur karakteristik kualitas informasi.

\section{c. Kualitas Pelayanan (Service Quality)}

perpustakaan sebagai penyedia informasi (information provider) sangat membutuhkan suatu sistem informasi yang tidak hanya menghasilkan produk informasi tetapi juga berupa pelayanan, maka pengukuran keefektifan sistem informasi tidak hanya terbatas pada kualitas informasinya saja, tetapi juga kualitas pelayanannya.

pengukuran kualitas pelayanan (service quality) semula digunakan untuk penelitian pemasaran. Penelitian-penelitan yang memasukan pengukuran kualitas pelayanan ke dalam model DeLone dan McLean meminjamnya dari peneliti pemasaran. Instrumen-instrumen yang digunakan untuk mengukur kualitas pelayanan (service quality) menurut Jogiyanto (2007:97) berisi dimensidimensi sebagai berikut:

1. Keandalan (reliability), seperti sistem informasi dapat diandalkan dalam mendukung pelayanan sirkulasi,

2. Daya tanggap (responssiveness), dengan menggunakan sistem informasi, staf perpustakaan dapat memberikan pelayanan segera kepada pengguna perpustakaan

3. Jaminan (assurance), dengan menggunakan sistem informasi, menjadikan staf perpustakaan mempunyai pengetahuan dan kemudahan untuk melakukan pekerjaannya dengan baik.

4. Empati (empathy), dengan sistem informasi, staf perpustakaan berkemampuan untuk memberikan perhatian yang bersifat individual atau pribadi kepada pengguna perpustakaan dan berusaha untuk memahami keinginan pengguna.

5. Bukti fisik (tangibles), penggunaan sistem informasi didukung dengan perangkat keras dan perangkat lunak yang mutakhir.

Kelima dimensi tersebut di atas yaitu keandalan, daya tanggap, jaminan, dan bukti fisik dijadikan sebagai indikator untuk mengukur karakteristik kualitas pelayanan.

\section{d. Minat Penggunaan Sistem (Intention to Use)}

penggunaan informasi (information use) adalah penggunaan keluaran suatu sistem informasi oleh penerima (Jogiyanto, 2007:19). Lebih lanjut Jogiyanto menjelaskan bahwa konsep penggunaan (use) dari suatu sistem dapat dilihat dari beberapa perspektif, yaitu penggunaan nyata (actual use), dan penggunaan persepsi (perceived use).

Beberapa penelitian menggunakan penggunaan nyata dengan mengukur banyaknya permintaan informasi dari manajer, atau dengan mencatat jumlah banyaknya waktu koneksi dari pemakai, atau jumlah penggunaan fungsi-fungsi komputer, jumlah catatan klien yang diproses, atau aktual biaya yang dibebankan untuk penggunaan komputer.

penggunaan persepsi adalah persepsi pemakai tentang penggunaan sistem informasi yang dianggap dilakukan olehnya.

Intensitas penggunaan nyata dan persepsi penggunaan dijadikan sebagai indikator untuk mengukur karakteristik minat penggunaan sistem.

\section{e. Kepuasan Pengguna Sistem (User Satisfication)}

Kepuasan bisa diartikan sebagai upaya pemenuhan sesuatu atau membuat sesuatu memadai (Tjiptono dan Chandra, 2005:195) Dengan demikian kepuasan pengguna sistem adalah persepsi seseorang pengguna sistem tentang harapannya yang telah terpenuhi atau terlampaui.

Kepuasan pengguna sistem (user satisfaction) merupakan respon dan umpan balik yang dimunculkan pengguna setelah memakai sistem informasi. Sikap pengguna terhadap sistem informasi merupakan kriteria subyektif mengenai seberapa suka pengguna terhadap sistem informasi yang digunakan.

pada karakteristik ini McGill dkk (2003:32) dalam penelitiannya menggunakan 3 (tiga) indikator untuk mengukur kepuasan pengguna, yaitu efisiensi (efficiency), keefektifan (effectiveness), dan kepuasan (satisfaction). Tiga indikator tersebut juga digunakan oleh Radityo dan Zulaikha (2007) dan Tjokronolo (2007) untuk mengukur kepuasan pengguna sistem, tetapi kedua peneliti terakhir masing-masing menambahkan 1 (satu) indikator kebanggaan menggunakan sistem (proudness) dan kebenaran (correctness).

Alat ukur pada karakteristik kepuasan pengguna ini, penulis menggunakan 4 (empat) indikator, sama dengan yang dilakukan oleh Tjokronolo (2007) yaitu kebenaran (correctness), efisiensi (efficiency), 
keefektifan (effectiviness), dan kepuasan (satisfaction).

\section{Kinerja}

Jika dilihat dari asal katanya, kata kinerja adalah terjemahan dari kata performance, yang menurut The Scribner-Bantam English Dictionary, terbitan Amerika Serikat dan Canada (1979) dalam Rivai (2005:14), berasal dari kata "to perform" dengan beberapa "entries" yaitu: (1) melakukan, menjalankan, melaksanakan (to do or carry out, execute); (2) memenuhi atau melaksanakan kewajiban suatu niat atau nazar (to discharge of fulfill; as vow); (3) melaksanakan atau menyempurnakan tanggung jawab (to executeor complete an understaking); dan (4) melakukan sesuatu yang diharapkan oleh seseorang atau mesin (to do what is expected of a person machine).

Stolovith and Keeps (1992) dalam Rivai (2005:14) mendefinisikan kinerja adalah seperangkat hasil yang dicapai dan merujuk pada tindakan pencapaian serta pelaksanaan sesuatu pekerjaan yang diminta. Sedangkan Schermerhorn dkk (1991) dalam Rivai (2005:15) kinerja sebagai kualitas dan kuantitas dari pencapaian tugas-tugas, baik yang dilakukan individu, kelompok maupun perusahaan.

Berdasarkan uraian di atas penulis dapat menyimpulkan bahwa kinerja adalah kesediaan seseorang atau kelompok orang untuk melakukan sesuatu kegiatan dan menyempurnakannya sesuai dengan tanggung jawabnya dengan hasil seperti yang diharapkan.

\section{Pelayanan Sirkulasi}

Kata sirkulasi dalam Kamus Umum Bahasa Indonesia berasal dari bahasa Inggris circulation berarti perputaran, peredaran seperti pada "sirkulasi udara, sirkulasi uang", dan lain sebagainya (Badudu, 1994: 1335)

Salah satu kegiatan utama atau jasa utama perpustakaan adalah peminjaman buku dan materi lainnya. Kegiatan peminjaman ini sering dikenal dengan nama pelayanan sirkulasi juga sering disebut dengan pelayanan peminjaman. Pelayanan sirkulasi merupakan ujung tombak pelayanan perpustakaan karena bagian inilah yang pertama kali berhubungan dengan pemakai serta paling sering digunakan pemakai.

Metode peminjaman sering kali disebut dengan sistem kendali sirkulasi atau sistem sirkulasi. Sistem peminjaman mengalami banyak perubahan, mulai dari sistem manual hingga ke sistem berbantuan komputer.

Menurut Sulistyo-Basuki (1993:260) sistem peminjaman harus mampu memberikan jawaban atas pertanyaan berikut:

1. Siapakah yang meminjam buku tertentu? Kapan tanggal kembalinya?

2. Buku apa saja yang dipinjamkan pada tanggal tertentu?

3. Buku dalam subyek apa saja yang dipinjam pada hari tertentu? Berapakah jumlah buku per subyek yang dipinjam?

4. Buku apa saja yang harus dikembalikan pada tanggal tertentu?

5. Berapa buku yang dikembalikan pada tanggal tertentu?

Dengan demikian sistem informasi perpustakaan yang dipilih hendaknya sistem yang memerlukan waktu tersedikit dalam hal peminjaman buku dan pengembalian buku, serta ekonomis sifatnya yang menyangkut hal tenaga, uang dan materi.

\section{E. Kinerja Pelayanan Sirkulasi}

Keberadaan dan pemakaian sistem informasi berpengaruh terhadap kualitas kinerja pengguna (pelayanan sirkulasi) secara organisasi dalam hal ini institusi yang menerapkan sistem informasi, termasuk di dalamnya produktivitas, efisiensi, dan efektivitas kerja (Radityo dan Zulaikha, 2007:14).

Siagian (1993:154) mendefinisikan produktivitas adalah kemampuan memperoleh manfaat yang sebesar-besarnya dari sarana dan prasarana yang tersedia dengan menghasilkan output yang optimal bahkan kalau mungkin yang maksimal.

Produktivitas mempunyai pengertian yang berhubungan dengan efektivitas dan efisiensi. Efisiensi lebih menekankan pada hasil kerja, efektivitas berhubungan dengan pencapaian tujuan yang telah dikaitkan dengan kerja manusia atau peningkatan tenaga kerja manusia, pembaharuan hidup dan kultural dan sikap mental memuliakan kerja serta perluasan upaya untuk meningkatkan mutu kehidupan masyarakat (Anoraga dan Suyati, 1995:123).

Produktivitas, efisiensi, dan efektifitas dijadikan sebagai indikator pengukuran kinerja pelayanan sirkulasi..

\section{F. Metode Penelitian}

Pada penelitian ini, subyek penelitiannya adalah staf Perpustakaan Universitas Gadjah Mada khususnya yang bertugas di bagian Pelayanan 
Sirkulasi dan staf bagian lain yang bertugas perpanjangan waktu (lembur) pelayanan sirkulasi di Perpustakaan Universitas Gadjah Mada. Obyek penelitiannya adalah Sistem Informasi Perpustakaan (SIPUS Terpadu Versi 3) di Perpustakaan Universitas Gadjah Mada

Penelitian ini termasuk dalam jenis penelitian survei, yaitu penelitian yang mengambil sampel dari satu populasi dan menggunakan kuesioner sebagai alat pengumpulan data yang pokok (Singarimbun, 1989:3).

Tujuan penelitian untuk mengetahui pengaruh penggunaan Sistem Informasi Perpustakaan (SIPUS Terpadu Versi 3) terhadap kinerja pelayanan sirkulasi di Perpustakaan Universitas Gadjah Mada. Pelaksanaan penelitian antara Juli - Agustus 2008. Metode penelitian yang penulis lakukan adalah metode korelasi. Menurut Hasan (2002:23) metode korelasi bertujuan untuk meneliti sejauh mana variabel pada satu faktor berkaitan dengan variasi pada faktor lainnya. Penelitian ini bertujuan untuk mengetahui pengaruh penggunaan sistem informasi perpustakaan (SIPUS Teradu Versi 3) terhadap kinerja pelayanan sirkulasi di Perpustakaan Universitas Gadjah Mada.

Metode pengumpulan data yang digunakan dalam penelitian ini adalah:

1. Angket atau kuesioner.

Angket atau kuesioner merupakan teknik pengumpulan data yang dilakukan dengan cara memberi seperangkat pertanyaan atau pernyataan tertulis kepada responden untuk dijawabnya. Kuesioner atau daftar pertanyaan disusun dengan memperhatikan/menerapkan Skala Likert, yaitu skala yang digunakan untuk mengukur sikap, pendapat, dan persepsi seseorang atau sekelompok orang tentang variabel penelitian. Dengan Skala Likert, maka variabel yang akan diukur dijabarkan menjadi indikator variabel. Kemudian indikator tersebut dijadikan sebagai titik tolak untuk menyusun item-item instrumen yang dapat berupa pernyataan atau pertanyaan (Sugiyono, 2004:86).

Jawaban setiap item instrumen yang menggunakan Skala Likert mempunyai gradasi dari sangat positif sampai sangat negatif, yang dapat berupa kata-kata antara lain:

$\begin{array}{ll}\text { Sangat Setuju(SS) } & \text { diberi nilai 5 } \\ \text { Setuju(S) } & \text { diberi nilai 4 } \\ \text { Kurang Setuju (KS) } & \text { diberi nilai 3 } \\ \text { Tidak Setuju(TS) } & \text { diberi nilai 2 } \\ \text { Sangat Tidak Setuju (STS) } & \text { diberi nilai 1 }\end{array}$

Untuk mengetahui pengaruh penggunaan sistem informasi perpustakaan terhadap kinerja pelayanan sirkulasi di Perpustakaan Universitas Gadjah Mada, disusun daftar pertanyaan (kuesioner), yang dibagikan kepada staf perpustakaan yang bertugas di pelayanan sirkulasi dan staf bagian lain yang mengambil perpanjangan waktu (lembur) di Pelayanan Sirkulasi Perpustakaan Universitas Gadjah Mada.

2. Observasi Observasi yaitu melakukan pengamatan secara langsung terhadap subyek penelitian. Dalam pengumpulan data khususnya penyebaran dan penarikan kuesioner peneliti yang menangani langsung tanpa dibantu oleh siapapun, karena sekupnya yang kecil dengan lokasi yang sangat dekat sehingga pelaksanaanya bisa dilakukan sendiri.

3. Dokumentasi

Untuk memperoleh data dan informasi yang mendukung penelitian ini, penulis mempelajari dokumen yang berhubungan dengan penelitian ini. Dokumen tersebut meliputi buku-buku, majalah/jurnal, laporan ilmiah yang berkaitan dengan permasalahan sistem informasi perpustakaan dan kinerja pelayanan sirkulasi perpustakaan.

\section{Hasil Penelitian}

Penyebaran kuesioner kepada operator SIPUS Terpadu Versi 3 sebanyak 40 responden dan dari kuesioner kembali semua dan layak untuk dianalisis. Setelah itu dilakukan uji analisis instrumen penelitian dengan uji validitas dan uji reliabilitas, kemudian dilakukan uji analisis pengaruh individual untuk mengetahui hubungan, dan setelah itu dilakukan uji analisis pengaruh variabel penggunaan Sistem Informasi Perpustakaan (SIPUS Terpadu Versi 3) terhadap kinerja pelayanan sirkulasi.

Berdasarkan data sebaran jawaban responden tentang Pengaruh Penggunaan Sistem Informasi Perpustakaan (SIPUS Terpadu Versi 3) Terhadap Kinerja Pelayanan Sirkulasi di Perpustakaan Universitas Gadjah Mada Yogyakarta. Dari 30 item pertanyaan dengan 26 indikator dan jumlah responden 40 orang, didapat 25 item pertanyaan dengan jawaban responden interprestasinya setuju, 3 item pertanyaan dengan jawaban responden interprestasinya kurang setuju dan 1 item pertanyaan dengan jawaban responden interprestasinya tidak setuju. Indikator yang jawaban responden dengan interprestasi kurang setuju adalah indikator keakuratan data pada sub 
variabel kualitas sistem, tepat pada waktunya pada sub variabel kualitas informasi dan kelengkapan pada sub variabel kualitas informasi. Indikator yang jawaban responden dengan interprestasi tidak setuju adalah indikator keandalan pada sub variabel kualitas sistem dan akurasi pada sub variabel kualitas informasi.

Dari hasil penelitian diketahui bahwa Penggunaan Sistem Informasi Perpustakaan (SIPUS Terpadu Versi 3) berpengaruh secara positif dan signifikan terhadap Kinerja Pelayanan Sirkulasi, dengan ditunjukkan oleh nilai t hitung sebesar 5,333 yang lebih besar dari nilai $t$ tabel dengan signifikansi $5 \%$ sebesar 2,024 . Hal ini diperkuat juga dengan diperolehnya angka signifikansi (sig) sebesar 0,000 lebih kecil dari 0,05 (signifikan) dan koefisien regresi sebesar 0,175 (positif) yang berarti ada pengaruh secara positif dan signifikan antara Penggunaan Sistem Informasi Perpustakaan (SIPUS Terpadu Versi 3) dan Kinerja Pelayanan Sirkulasi.

Berdasarkan Pedoman Uji Signifikansi Korelasi Product Moment, maka koefisien determinasi adjusted $R 2$ sebesar 0,413 yang termasuk dalam kategori sedang, terdapat pengaruh yang tingkatannya sedang antara Penggunaan Sistem Informasi Perpustakaan (SIPUS Terpadu Versi 3) dan Kinerja Pelayanan Sirkulasi. Jadi dari uji koefisien determinasi tersebut didapati hasil kategori yang termasuk dalam kategori sedang.

Hal ini dapat diterangkan bahwa Penggunaan Sistem Informasi Perpustakaan (SIPUS Terpadu Versi 3) yang digunakan di Perpustakaan Universitas Gadjah Mada Yogyakarta dapat mempengaruhi Kinerja Pelayanan Sirkulasi, dan yang menjadi fokus dalam otomatisasi perpustakaan adalah sistem, sumber informasi dan pengguna terkoneksi, dimana perkembangan komputer akan diikuti dengan perkembangan dalam penggunaan jaringan dan internet. Sistem informasi manajemen perpustakaan terintegrasi yang menerapkan modulmodul standar seperti: sirkulasi, pengkatalogan, pengadaan, akses katalog online dan jaringan kerjasama melalui fasilitas internet dapat lebih mempermudah pengguna pelayanan perpustakaan lebih baik lagi. Namun demikian, dilihat dari nilai koefisien determinasi atau adjusted $R$ square, kebenaran model Penggunaan Sistem Informasi Perpustakaan (SIPUS Terpadu Versi 3) mempengaruhi Kinerja Pelayanan Sirkulasi dalam kategori sedang, yaitu $41,3 \%$. Kinerja pelayanan sirkulasi dapat ditingkatkan dengan variabelvariabel lain misalnya pemberdayaan sumber daya manusia, kompensasi, lingkungan kerja fisik. Dalam penelitian ini, variabel-variabel lain yang mempengaruhi terhadap kinerja pelayanan sirkulasi tersebut tidak diteliti, sehingga tidak dibahas lebih lanjut.

\section{Kesimpulan}

Berdasarkan pembahasan hasil penelitian dapat ditarik simpulan sebagai berikut:

1. Hasil skor kesetujuan jawaban responden didapat 4 (empat) indikator sub variabel sistem informasi perpustakaan yaitu kualitas sistem, kualitas pelayanan, minat penggunaan sistem, kepuasan pengguna sistem diinterprestasikan setuju, dan 1 (satu) indikator sub variabel. kualitas informasi diinterprestasikan kurang setuju. Sedangkan skor kesetujuan jawaban responden untuk indikator Kinerja Pelayanan Sirkulasi diinterprestasikan setuju. 2. Hasil penelitian ini menunjukan hipotesis penelitian yang menyatakan bahwa ada pengaruh positif dan signifikan Penggunaan Sistem Informasi Perpustakaan (SIPUS Terpadu Versi 3) terhadap Kinerja Pelayanan Sirkulasi di Perpustakaan Universitas Gadjah Mada, dapat diterima.

3. Penggunaan Sistem Informasi Perpustakaan (SIPUS Terpadu Versi 3) dengan segala macam indikatornya mempengaruhi Kinerja Pelayanan Sirkulasi di Perpustakaan Universitas Gadjah Mada.

4. Penggunaan Sistem Informasi Perpustakaan (SIPUS Terpadu Versi 3) berpengaruh secara positif dan signifikan terhadap Kinerja Pelayanan Sirkulasi di Perpustakaan Universitas Gadjah Mada, dengan ditunjukkan oleh angka signifikansi (sig) sebesar 0,000 lebih kecil dari 0,05 (signifikan) dan koefisien regresi sebesar 0,175 (positif).

5. Variabel Kinerja Pelayanan Sirkulasi dipengaruhi oleh variabel Penggunaan Sistem Informasi Perpustakaan (SIPUS Terpadu Versi 3) sebesar $41,3 \%$, hal tersebut ditunjukkan dengan nilai adjusted $\mathrm{R}$ square sebesar 0,413 , sedangkan sisanya sebesar $58,7 \%(100 \%$ $41,3 \%$ ) dijelaskan oleh variabel yang lain diluar model.

\section{Saran}

1. Berdasarkan hasil penelitian ini penggunaan Sistem Informasi Perpustakaan (SIPUS Terpadu Versi 3) terdapat pengaruh yang tingkatannya sedang antara Penggunaan Sistem Informasi Perpustakaan dan Kinerja Pelayanan Sirkulasi, maka seyogyanya Perpustakaan UGM dapat lebih meningkatkan lagi keakuratan 
datanya, sehingga dapat meningkatkan Kinerja Pelayanan Sirkulasi di Perpustakaan Universitas Gadjah Mada.

2. Kepada pihak pengembang untuk meningkatkan kualitas SIPUS Terpadu Versi 3 dengan menjadikan Sistem Informasi Perpustakaan yang memiliki kekonsistenan waktu atau tepat pada waktunya, informasi yang akurat, dan sistem yang handal yaitu terhindar dari error atau macet ditengah jalan, sehingga ke depan tercapai kesuksesan Sistem Informasi Perpustakaan di Perpustakaan Universitas Gadjah Mada.

\section{DAFTAR PUSTAKA}

Amsyah, Zulkifli. 2001. Manajemen Sistem Informasi. Jakarta : Gramedia Pustaka Utama

Anoraga, Pandji dan Sri Suyati. 1995. Perilaku Keorganisasian. Jakarta: Dunia Pustaka Jaya.

Arikunto, Suharsimi. 1997. Prosedur Penelitian : Suatu Pendekatan Praktek. Jakarta : Rineka Cipta.

Badudu, 1994. Kamus Umum Bahasa Indonesia. Jakarta: Pustaka Sinar Harapan

Dikti, 2004. Perpustakaan Perguruan Tinggi: Buku Pedoman. Jakarta : Depdiknas RI Dirjen Dikti.

Fuad, Noor. 1988. Analisis dan Perancangan Sistem. Jakarta: Intermedia.

Gamatechno. tt. SIPUS versi 3.0 : Panduan Bagi Operator. Yogyakarta: Gamatechno.

Ghozali, Imam. 2005. Aplikasi Analisis Multivariate dengan Program SPSS. Semarang: Badan Penerbit Universitas Diponegoro

Gibson, James dkk. 1996. Organisasi. Jakarta : Binarupa Aksara. Gujarati, Damodar Cardosa. 1995. Ekonometrika Dasar. Jakarta : Erlangga.

Gunawan, Ade. 2002. "Memanage Performance Karyawan melalui Pemberian Kompensasi". Dalam Jurnal Ilmiah Manajemen \& Bisnis. Program Studi Manajemen, Fakultas Ekonomi, Universitas Muhammadiyah Sumatera Utara. Vol. 02 No. 02 Oktober 2002

Hak, Ade Abdul. 2005. Rencana Strategis dan Standar Cobit untuk Sistem Informasi Perpustakaan Terintegrasi dalam Mewujudkan Universitas Bertaraf Internasional. Jakarta: (t.p.). Hasan, M. Iqbal. 2002. Pokok-pokok Materi Metodologi Penelitian \& Aplikasinya. Jakarta: Ghalia Indonesia.

Indrajit, Richardus Eko. 2000. Pengantar Konsep
Dasar Manajemen Sistem Informasi dan Teknologi Informasi. Jakarta: PT Elex Media Komputindo

Jogiyanto, 2005. Analisis \& Disain Sistem Informasi: Pendekatan Terstruktur Teori dan PraktekAplikasi Bisnis. Yogyakarta:Andi.

Jogiyanto. 2007. Model Kesuksesan Sistem Teknologi Informasi. Yogyakarta: Andi

Karya, Gede. 2004. "Pengembangan Model Audit Sistem Informasi Berbasis Kendali". Dalam Integral, Vo. 9 No. 1. Maret 2004.

Notohadiprawiro, Tejoyuwono. 1990. Sistem Informasi dan Kepentingannya. Makalah Seminar Nasional Plantagama, Fakultas Pertanian UGM. 27 Oktober 1990.

McGill, Tanya dkk. (2003). "User-Developed Applications and Information Systems Success: A Test of DeLone and McLean's Model". Dalam Information Resources Management Journal, 16(1), 24-45, Jan-Mar 2003.

Oetomo, Budi Sutedjo Dharma. 2006. Perencanaan \& Pembangunan Sistem Informasi. Yogyakarta: Andi.

Perpustakaan Universitas Gadjah Mada. 2007. Buku Panduan Perpustakaan Universitas Gadjah Mada. Yogyakarta : Perpustakaan UGM

Qalyubi, Syihabuddin dkk. 2003. Dasar-dasar Ilmu Perpustakaan dan Informasi. Yogyakarta : Jurusan Ilmu Perpustakaan dan Informasi, Fakultas Adab UIN Sunan Kalijaga Yogyakarta

Radityo, Dody dan Zulaikha. 2007. "Pengujian Model DeLone and McLean Dalam Pengembangan Sistem Informasi Manajemen (Kajian Sebuah Kasus). Dalam Simposium Nasional Akuntansi UNHAS Makasar 26-28 Juli 2007

Rivai, Veithzal dan Ahmad Fawzi Mohd. Basri. 2005. Performance Appraisal : Sistem yang Tepat untuk Menilai Kinerja Karyawan dan Meningkatkan Daya Saing Perusahaan. Jakarta : RajaGrafindo Persada.

Saleh, Abdul Rahman. 2006. "Program Otomasi untuk Meningkatkan Kinerja Perpustakaan". D a 1 a m h t p : / / b p i b teknologi.blogspot.com/2006 0601 archive.html, tanggal 18 Februari 2008, pukul 15.30 WIB

Sarwono, Jonathan. 2007. Analisis Jalur untuk Riset Bisnis dengan SPSS. Yogyakarta: ANDI

Siagian, Sondang P. 2001. Sistem Informasi Manajemen. Jakarta: Bumi Aksara 
Kepemimpinan \& Perilaku Administrasi. Jakarta: Haji Masagung

Simamora, Bilson. 2004. Panduan Riset Perilaku Konsumen. Jakarta : Gramedia Pustaka Utama.

Singarimbun, Masri dan Sofian Effendi. 1989. Metode Penelitian Survei. Jakarta : LP3ES.

Siregar, A. Ridwan. 2004. Perpustakaan: Energi Pembangunan Bangsa. Medan : USUPress.

Sugiyono, 2007. Statistika untuk Penelitian. Bandung : Alfabeta. ,2004. Metode Penelitian untuk Bisnis. Bandung: Alfabeta.

Sulistyo-Basuki. 1993. Pengantar Ilmu Perpustakaan. Jakarta : Gramedia Pustaka Utama
1994. Periodisasi Perpustakaan Indonesia. Bandung: Remaja Rosdakarya

Surachman, Arif. 2007. Analisis Penerimaan Sistem Informasi Perpustakaan (SIPUS) Terpadu versi 3 (tiga) di lingkungan Universitas Gadjah Mada. Fakultas Adab UIN Sunan Kalijaga Yogyakarta

Surachman, Winarno. 1975. Dasar dan Teknik Research. Bandung : Tarsito

Tjokronolo, Lutvi Hadib. 2007. "Peranan Sistem Informasi Keuangan Terhadap Kinerja Perusahaan" (thesis). Sekolah Pascasarjana Universitas Gadjah Mada Yogyakarta. 